\title{
Predatory Stink Bug, Alcaeorrhynchus grandis (Dallas) 1
}

\section{B. Richman and F. W. Mead ${ }^{2}$}

\section{Identification}

Alcaeorrhynchus grandis (Dallas) is a very large $(20 \mathrm{~mm})$ predatory stink bug which occurs in several row crops and preys on other insects, especially lepidopterous larvae. The stages in the life cycle have never been illustrated and are presented here so that they can be identified in the field.

\section{Distribution}

A. grandis has been reported from Colombia, Mexico, Florida, and Texas. The Florida State Collection of Arthropods has several specimens collected in 1973 through 1975 at Edgard and Prairieville, Louisiana by Vernon Brou. Florida records are from the entire peninsula and at least as far west and north as Jackson County.

\section{Life Cycle}

A. grandis was reared in the laboratory by Richman and Whitcomb (1978). At variable temperatures averaging 26 degrees $\mathrm{C}$ and at a constant temperature of 27 degrees $C$ (both at 14:10 photoperiod) the time from egg to adult lasted 59 to 60 days, with the egg stage taking 15 to 16 days.

\section{Eggs}

Approximately $1 \mathrm{~mm}$ in diameter, with short projections around operculum; laid 100 to 200 at a time in multiple row masses. (On soybean stems these masses are usually four to five rows wide, but may be as much as 10 rows wide on paper toweling in the laboratory.)

\section{Nymphs}

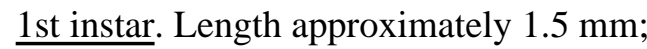
humeral width $0.9 \mathrm{~mm}$. These are difficult to distinguish from the first instar nymphs of Euthyrhynchus floridanus (Linnaeus); both have a blue- black head and thorax and red abdomen with dark central and lateral "stripes" composed of dorsal and lateral dark colored plates. Nymphs of this age do not stray far from the egg mass and may be distinguished by the form of the mass and numbers of eggs; E. floridanus masses are loosely oval and contain 20 to 90 eggs.

2nd instar. Length approximately $3 \mathrm{~mm}$; humeral width $1.3 \mathrm{~mm}$. A. grandis begins to capture insect prey in the 2 nd instar. At this stage the nymph has

1. This document is EENY-165 (originally published as DPI Entomology Circular 192), one of a series of Featured Creatures from the Entomology and Nematology Department, Florida Cooperative Extension Service, Institute of Food and Agricultural Sciences, University of Florida. Published: October 2000. This document is also available on Featured Creatures Website at http://creatures.ifas.ufl.edu. Please visit the EDIS Website at http://edis.ifas.ufl.edu.

2. D. B. Richman, Institute of Food and Agricultural Sciences, University of Florida, Gainesville, FL, F. W. Mead, Florida Department of Agriculture and Consumer Services, Division of Plant Industry, Gainesville, FL.

The Institute of Food and Agricultural Sciences is an equal opportunity/affirmative action employer authorized to provide research, educational information and other services only to individuals and institutions that function without regard to race, color, sex, age, handicap, or national origin. For information on obtaining other extension publications, contact your county Cooperative Extension Service office. Florida Cooperative Extension Service/Institute of Food and Agricultural Sciences/University of Florida/Christine Taylor Waddill, Dean. 


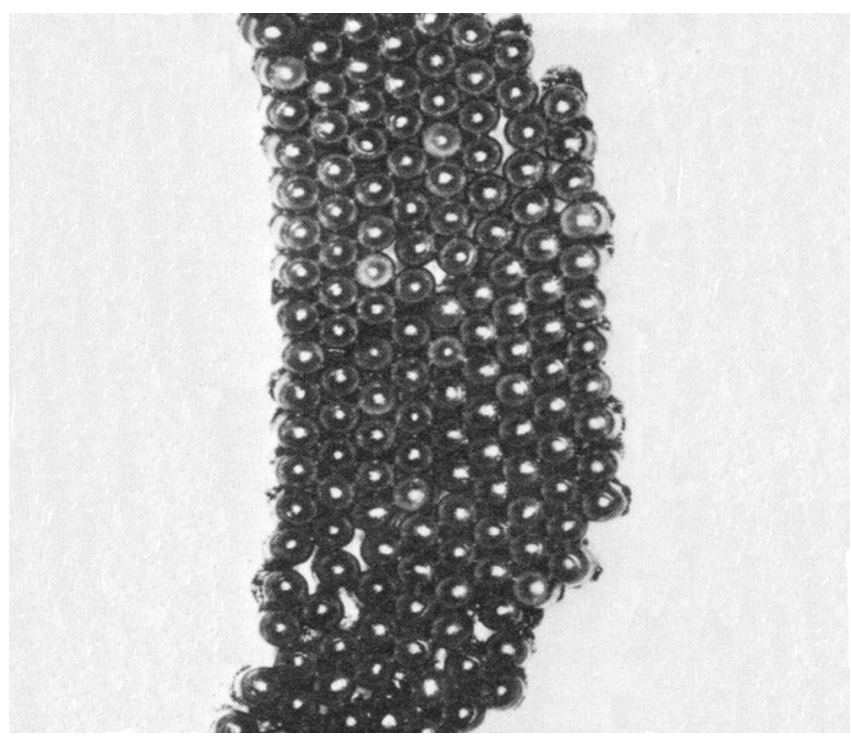

Figure 1. Eggs of the predatory stink bug, Alcaeorrhynchus grandis (Dallas). Credits: Division of Plant Industry
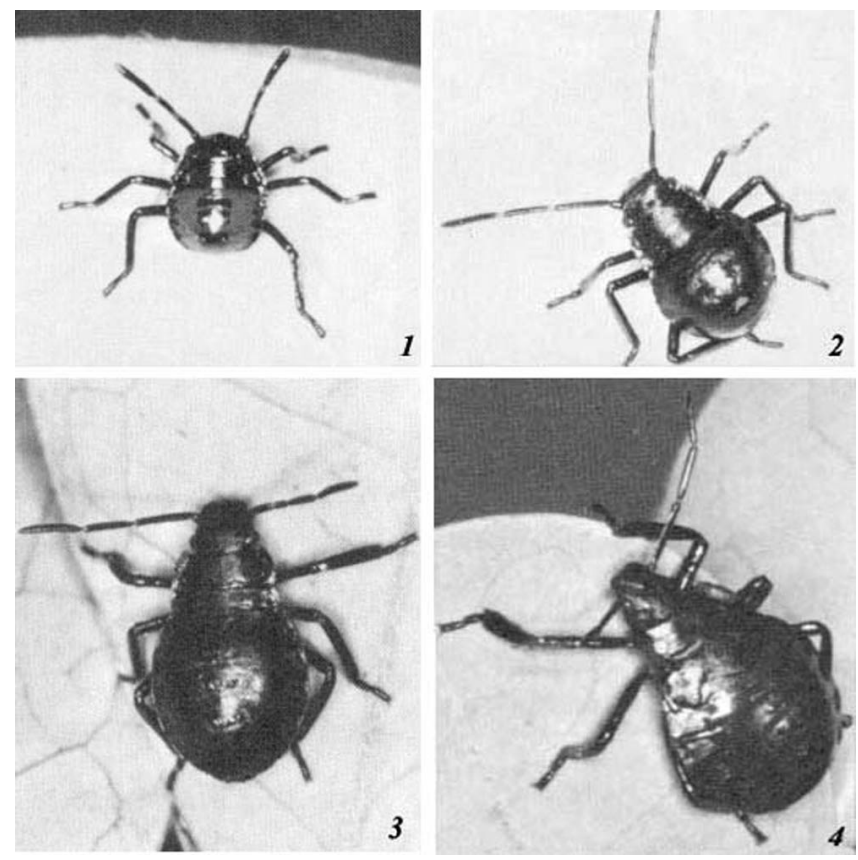

Figure 2. First four instars of the predatory stink bug, Alcaeorrhynchus grandis (Dallas) - 1) first instar, 2) second instar, 3) third instar and 4) fourth instar. Credits: Division of Plant Industry

differentiated somewhat from the color of the 2nd instar nymph of $E$. floridanus and has become more uniformly brownish with faint markings on the abdomen.

3rd instar. Length 4-5 mm; humeral width 2.3 $\mathrm{mm}$. At this stage the nymph has acquired red lateral keels on the pronotum and is generally bluish black with a brownish abdomen. 4th instar. Length 7-8 mm; humeral width 3.8 $\mathrm{mm}$. The 4th instar nymph has larger red lateral keels on the pronotum. The general color of the nymph is bluish black. The wing pads are visible, but not prominent.

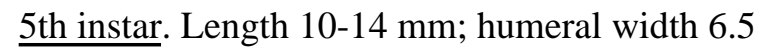
$\mathrm{mm}$. The 5th instar nymph has distinct wing pads and very large red lateral keels on the pronotum.

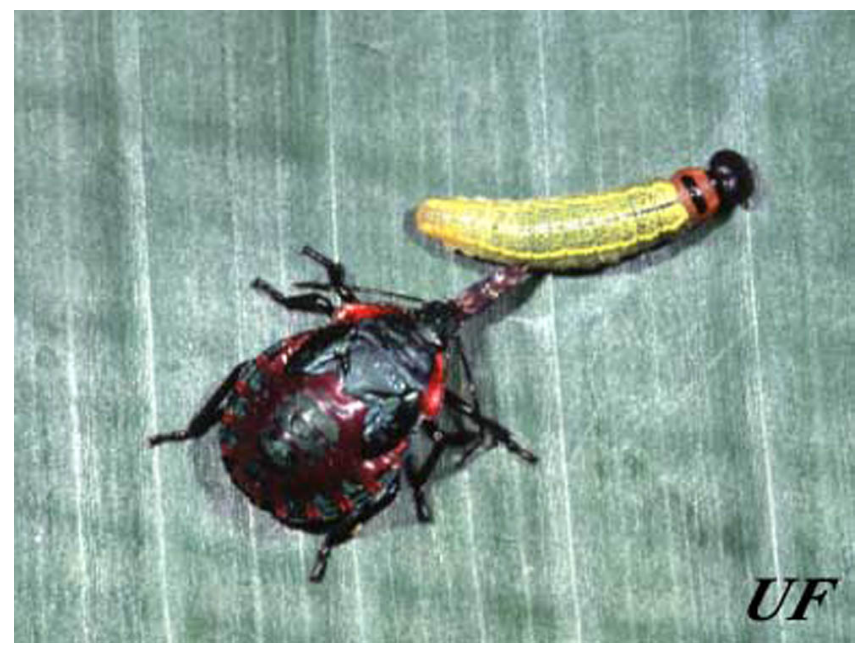

Figure 3. Fifth instar nymph of the predatory stink bug, Alcaeorrhynchus grandis (Dallas), with distinct wing pads. Credits: University of Florida

\section{Adults}

Male length 16-21 mm; humeral width 9-12 mm (including spines). Female length $18-25 \mathrm{~mm}$; humeral width 11-14 mm (including spines). The adults have double spines on the humeral angles. The adults of $A$. grandis are variegated brown in color, with dark bands on the legs and dark maculations along the dorsolateral margins of the abdomen. They are the largest predatory stink bugs in Florida and generally resemble Podisus maculiventris (Say), from which they can be distinguished by their larger size and double, rather than single, humeral spines.

\section{Economic Importance}

Although little has been written on this species, it has been reported to be an important predator of soybean pests in Florida (Watson 1916, Whitcomb 1973). It has also been reported to be a pest on eggplant (Watson 1922), but damage to any crops from this species is probably exceptional. 


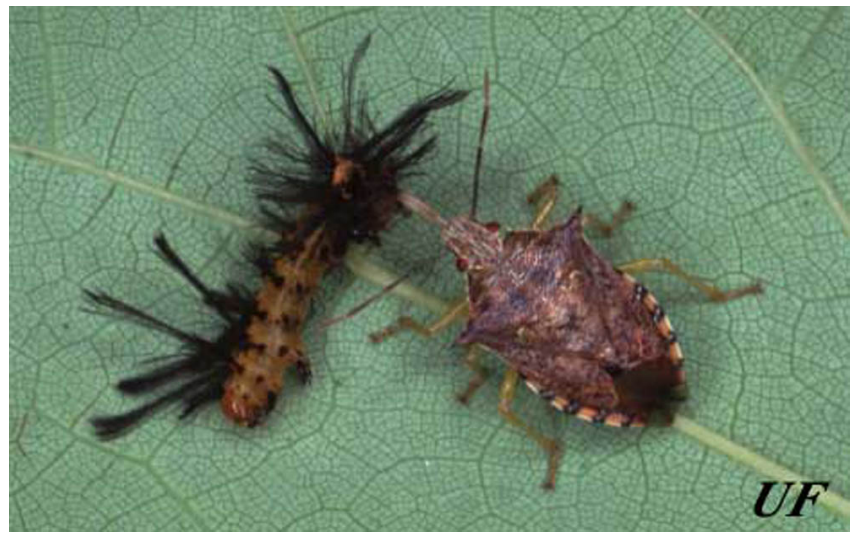

Figure 4. Adult of the predatory stink bug, Alcaeorrhynchus grandis (Dallas), feeding. Credits: University of Florida

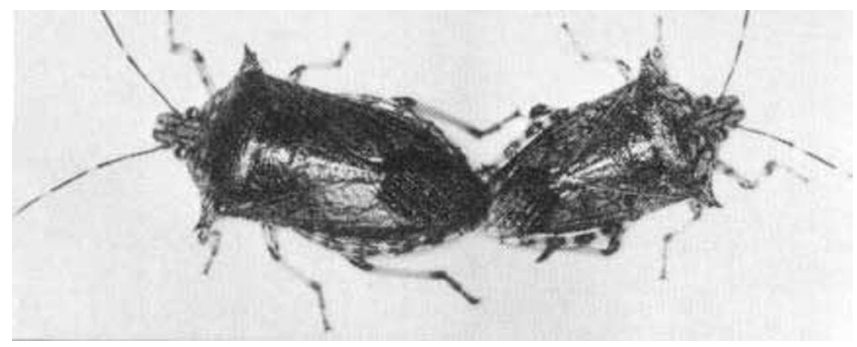

Figure 5. Mating adults (male on right) of the predatory stink bug, Alcaeorrhynchus grandis (Dallas). Credits: Division of Plant Industry

\section{Selected References}

Richman, D.B., and W.H. Whitcomb. 1978. Comparative life cycles of four species of predatory stink bugs (Hemiptera: Pentatomidae). Florida Entomologist 61, p 113-119.

Watson, J.R. 1916; Control of the velvetbean caterpillar. Florida Agricultural Experiment Station Bulletin 130: 45-58.

Watson, J.R. 1922. Report of entomologist. Pages 56R-59R in W. Newell. Agric. Exp. Sta. Rept. for the fiscal year ending June 30, 1922. Univiversity of Florida, Gainesville.

Whitcomb, W.H. 1973. Natural populations of entomophagous arthropods and their effect on the agroecosystem. Proc. Mississippi Symp. Bio. Control, Univiversity Press of Mississippi. p. 150-169. 